\title{
Navigating Special Education Law as a Rural School Administrator
}

\author{
Laura Trujillo-Jenks, Ph.D. \\ College of Professional Education, Texas Woman's University \\ P.O. Box 425769, Denton, Texas 76204-5769 \\ Tel: 1-940-898-2447Ｅ-mail: 1trujillojenks@twu.edu \\ Teresa Starrett, Ed.D. (Corresponding Author) \\ College of Professional Education, Texas Woman's University \\ P.O. Box 425769, Denton, Texas 76204-5769 \\ Tel: 1-940-898-2449_E-mail: tstarrett@twu.edu
}

\begin{abstract}
Received: February 7, 2014 Accepted: February 25, 2014 Published: May 15, 2015
doi:10.5296/jet.v2i2.7603 URL: http://dx.doi.org/10.5296/jet.v2i2.7603
\end{abstract}

\begin{abstract}
Working in a rural school district has some great advantages as well as disadvantages. One disadvantage is the lack of resources, such as an alternative discipline placement for students who violate the student code of conduct. This case study, or fictional scenario, focuses on one principal's need to understand much more about alternative discipline placements for students who violate both the student code of conduct and the penal code. This is not based on real research, but is an application-based case study that can be used in a graduate course in educational leadership. All names used are fictional. Additionally, this case study or fictional scenario is presented as follows: Educational leadership issue, literature review to support the issue, and teaching notes and guiding questions to expound on the issue.
\end{abstract}

Keywords: Special education, Rural schools, Student discipline

\section{Willow Springs School District}

The City of Willow Springs is a rural city about 30 miles from a large urban metropolitan area. The population of the city is 2,009 with a district population of 759 . There are 63 teachers and eight teacher aides working within the district and one administrator assigned to each of three campuses- elementary, middle and high school. The superintendent, the deputy superintendent, and five secretaries are housed in the administrative building, which sits on the same acreage as all three campuses. 
Due to the lower teacher pay compared to surrounding districts and the need to have highly qualified teachers, many of the teachers were hired to teach multiple disciplines. For example, the high school business teacher also teaches algebra II, while the middle school drama teacher also teaches sophomore English. Additionally, due to the low numbers of students on each campus, the school board has only approved a principal to serve as the sole administrator per campus. Without an assistant principal, these principals are essentially responsible for all administrative duties on their own.

Willow Springs Independent School District (WSISD) is considered poor within the State of Texas. This means that many curriculum courses, such as Advanced Placement or Advancement Via Individual Determination (AVID) are not offered. This also means that many special programs are offered through a Cooperative: A central place where many rural districts pay a fee to have access to specialists and specially designed instructional placements and sites. For example, WSISD is a part of the McKinney County Special Education Cooperative (MCSEC), where seven other rural districts share the cost of having special education staff, such as diagnosticians, psychologists, and behavioral specialists readily available for their students.

\section{Willow Springs High School}

Willow Springs High School (WSHS) is a school that focuses on student success. The students may not have many courses to choose from compared to bigger and more affluent schools, but the teachers are determined to ensure that their students are prepared to graduate from high school with the skills needed to succeed. Nearly $70 \%$ of the students who graduate from WSHS, enter four-year universities, and graduate with a Bachelor's Degree. Roughly $30 \%$ of students take advantage of the Career and Technology Education (CATE) courses and earn state certifications, such as in cosmetology and auto-repair, and find lucrative jobs in their area of interest and expertise.

The teachers have longevity and there are few who leave the school. However, there are high turnover rates among the coaches and band directors: Both sets of teachers continuously seek to become head coaches and directors in larger schools. Nevertheless, the teachers are seen as a fixture of the school, which helps students feel comfortable. Many teachers grew up in Willow Springs and graduated from WSHS, earned a degree in teaching, and eventually came back to Willow Springs to teach. The tight knit community recognizes these teachers as giving back to the community; hence, the community is a great supporter of the schools.

The Willow Springs community includes parents, business people, those who work for the city, and surrounding farm and ranch families that live near. Because Willow Springs is such a small town, it is easy for the community members to know each other, and support, and help each other. These members also have expectations for themselves and each other, which translates to disciplining children and guiding them to grow up as Christians who need to do for themselves and not rely on anyone for a handout. The community and the schools have a great partnership and parents understand that they are expected to be in their child's school life. Therefore, the parental support is at $88 \%$, which correlates directly to high student achievement and fewer overall discipline problems. Hara and Burke (1998) found that 
increased parental involvement paired with community support generally results in increased student gains.

\section{The WSHS Principal}

The high school principal, Paul Murphy, is an example of the district's "grow your own" policy. Mr. Murphy was born in Willow Springs and is a product of the school he now leads. Though he left the city to earn his Bachelor's Degree, he returned to teach and settle down with his wife and two children. Because of the remote nature of Willow Springs, Mr. Murphy earned his principal credentials through the regional service center, which provided a program solely over the course of one summer. He has been the high school principal for four years and has found there to be few issues with failing academics or discipline when it comes to the students at WSHS, which again is due to the high parental involvement. Mr. Murphy has the added benefit of having grown up with many of the parents of students he now serves.

Because of the low student enrollment, Mr. Murphy is the only administrator at Willow Springs High School, which has a student population of 198. Of that student population, 17 students receive special education services through McKinney County Special Education Cooperative (MCSEC), which include services for learning disabilities and other health impaired (i.e., Attention Deficit Disorder, or ADD). When a student needs more services than those that are provided at Willow Springs, a special education coordinator from MCSEC is contacted and the procedures to find a least restrictive placement is sought. After a least restrictive placement is found, transportation is provided for the student to the school regardless of location. This is often at a high cost to the district as MCSEC serves a total of eight rural school districts that occupy about 97 square miles.

\section{The New Student}

Corey Henderson, an impulsive and arrogant 16 year old student, moved with his family to the City of Willow Springs one month ago from another state. When he came to register for school with his mother, the principal, Mr. Murphy, was informed that Corey had been placed in an alternative discipline setting prior to withdrawing from his previous school. The mother was up front with Mr. Murphy about the situation, and because of her perceived honesty, Mr. Murphy allowed Corey to attend classes at Willow Springs until the official records from his previous school were received. Mr. Murphy did contact Corey's previous school and found that the information that Mrs. Henderson gave was true, and he found out that Corey was a student in special education with an emotional disability.

Corey's previous placement was at a large urban school district and at a high school with a student population of nearly 4,500. Corey was a part of a well-known gang and had been arrested twice: Once for theft of food at age 13, and once, at age 16, for burgling a home while the family was asleep. Since he was a minor in both cases, he was sent to a Juvenile Justice Alternative Education Placement (JJAEP) for nearly a year for both incidents, and then eventually he was able to return to his home campus.

Unfortunately, while Mr. Murphy waited for Corey's academic paperwork from his previous school, Corey wreaked havoc on the students and staff at WSHS for nearly one month. He 
was disrespectful and disruptive in the classroom; thus, requiring frequent interventions by Mr. Murphy. Because Mr. Murphy's greatest experience with discipline included minor infractions, such as tardiest and insubordination, he found himself unable to adequately support his teachers with Corey. Additionally, Mr. Murphy did not have the rapport and relationship with Corey's mother as he did with the majority of the students' parents. Soon, Corey's behavior became volatile and a placement out of WSHS was warranted, especially since within a week's time, he disrupted his English class and shouted, "I need to relieve myself on someone hot and bothered!" he walked out of three classes after roll was taken, and he punched a female student in the mouth for laughing "too loudly". The female student needed seven stitches.

\section{The Consequence for Misbehavior}

When these violations of the student code of conduct occurred, Mr. Murphy placed Corey in In-School Suspension (ISS). However, ISS didn't seem to work, because his behavior seemed to escalate within the ISS classroom to the point where he consistently used profanity and threw books and pens across the room. Because this type of student outburst was new to $\mathrm{Mr}$. Murphy, he asked for guidance from the superintendent, Dr. Alice Jortle, who advised him to set a discipline hearing within three days to discuss placement in an alternative setting, such as the Aim High program (a behavior adjustment class). She also advised Mr. Murphy that a manifestation determination meeting would need to be set before the discipline hearing. Finally, Dr. Jortle asked what consequences occurred after the female student was punched in the mouth, to which Mr. Murphy stated, "I'm setting a discipline hearing for Corey." When Dr. Jortle asked if the female student would be filing charges for the assault, Mr. Murphy said he would ask her and her parents before the discipline hearing. Mr. Murphy felt behind an eight ball; he was happy that Dr. Jortle guided him on what steps to take.

Since WSHS did not have a behavior unit on the campus, students are sent to the MCSEC Aim High behavioral unit. In fact, all school districts that are a part of the MCSEC send students who need to be placed in a behavioral unit to the Aim High program, which is located in another rural town about 15 minutes from Willow Springs. Mr. Murphy contacted Corey's mother and explained the need for a discipline hearing to determine an alternative placement for Corey, which he believed would be at the MCSEC Aim High behavioral unit since Corey is a special education student. He explained that Dr. Jortle would be the hearing officer who would have the final say of where Corey would be placed.

At the hearing, Corey's mother became argumentative and stated she did not wish for her son to be bused to Aim High because of the long distance. She stated this was an unreasonable addition to his day and demanded a closer placement, and also indicated the idle time on the bus may present a danger to others; therefore, the district would be derelict in their duties to keep students safe by making this placement. Corey's mother argued that she didn't care what kind of hearing needed to occur; she would never agree to Corey being placed at Aim High.

Because the parents of the female student wanted to pursue filing charges against Corey for assault, a possible arrest could occur, which would place Corey at JJAEP. Mr. Murphy 
wondered if he should just allow the arrest to happen and then he wouldn't have to worry about a discipline hearing or dealing with Corey or his mother; so he thought. He now wished he placed Corey in an alternative setting when he registered a month ago.

\section{Literature Review}

\subsection{Rural Schools and Their Resources}

Though the needs of schools in a rural setting differ from those in a larger urban setting, the expectations of behavior are generally the same. According to the Texas Education Agency, 448 of the roughly 1,032 school districts are classified as rural. Rural, in Texas is defined as "an enrollment of between 300 and the median district enrollment for the state and an enrollment growth rate over the past five years of less than 20 percent; or an enrollment of less than 300 students" (TEA, 2013). Small districts face unique challenges both with resources and staffing.

According to the National Education Association (2013), rural schools often are impacted negatively in regards to funding based upon a lack of a steady revenue stream. In Texas, funding is generally based upon a per pupil allocation. Obviously, if student enrollment is minimal, the total amount distributed to the district is minimal. While districts also receive federal funding, this accounts for less than $10 \%$ overall. Rural school districts must be creative in the use of money and personnel, thus requiring many individuals to serve multiple functions, such as the principal teaching a class or a teacher being responsible for multiple extracurricular activities. The results of this lack of funding are many. Teachers generally receive lower salaries and benefits, experience a lack of access to high quality professional development, and experience professional isolation.

\subsection{Student Discipline}

Disciplining students in special education gives many school administrators a time to pause because they become nervous due to the federal mandates outlined in the Individual's with Disabilities Education Act, or IDEA. However, disciplining a student in special education should follow the same thoughtful steps as disciplining a student in general education. Students must be held accountable for their actions, whether that means a Functional Behavioral Assessment (FBA) and/or a Behavioral Intervention Plan (BIP) are created, or a student is arrested and sent to JJAEP or jail. The bottom line is that the safety and order of the whole campus should never be sacrificed due to the lack of discipline standards for students in special education. As Dwyer (1997) stated, "There is nothing in IDEA that restricts schools from disciplining children with disabilities. In fact, some would say that, by not addressing these dangerous behaviors, the student with special needs is not receiving an 'appropriate' education" (paragraph 4).

Additionally, students in special education who do need to be placed in another academic setting due to their behaviors, such as a District Alternative Education Placement (DAEP) or JJAEP, must have a manifestation determination meeting. During this meeting, two questions are answered by the committee, per 34 CFR $\S 300.530(\mathrm{e}): 1)$ Is the conduct a direct result of the district's failure to implement the IEP (Individualized Education Plan); and 2) Does the 
conduct have a direct and substantial relationship to the disability? Possible results from these questions follow. First, when the committee agrees the IEP was implemented appropriately and there is a link between the student's behavior and his/her disability, the committee may agree that the student will stay on campus. If an FBA or a BIP have not been put in place, both are required immediately. Additionally, a more restrictive environment, such as a behavior adjustment classroom, may be considered for the student. Second, if the committee agrees that the IEP was implemented appropriately and there is no link between the student's behavior and disability, the student will be sent to the alternative placement, where he/she will receive academic services, both in general and special education, as prescribed by the IEP.

In summation, the following could occur after the two questions are asked:

1) Is the conduct a direct result of the district's failure to implement the IEP

(Individualized Education Plan); and

2) Does the conduct have a direct and substantial relationship to the disability?

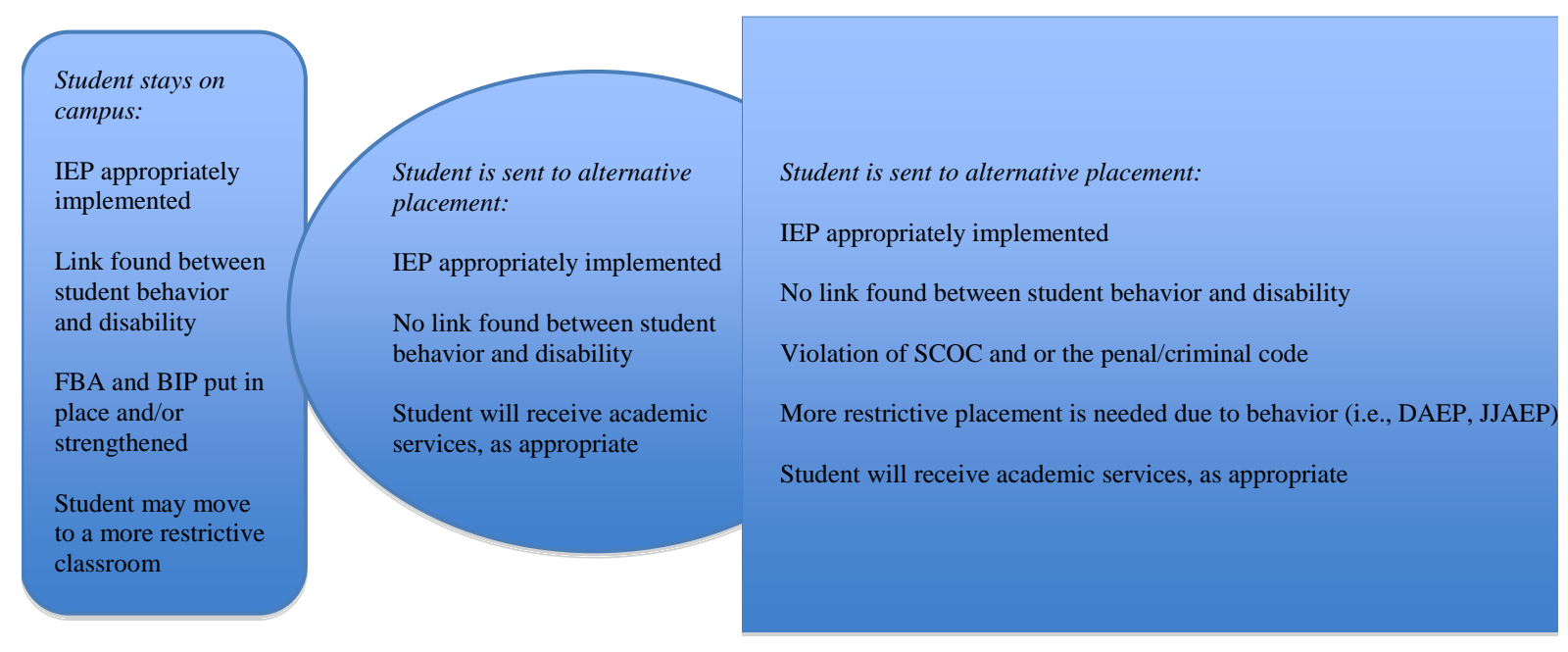

Figure 1. Three types of discipline and possible results when the two questions are asked

When a student has violated the student code of conduct (SCOC) and the penal or criminal code, and the behavior they displayed is linked to his/her disability, then things may get a bit complicated. A parent must agree with the committee for their child to be removed from the school and placed in an alternative setting when there is a link. However, the school may still discipline the student by placing the student in a more restrictive setting (i.e., socially adjusted classroom) and implement a BIP. Moreover, if it is shown that there is a link between the student's behavior and disability, parents may agree and request that the child still be sent to the DAEP or JJAEP, as appropriate. 
Several court cases highlight the different possibilities that may come from disciplining students who are in special education; however, the majority of cases dealt with suspensions and not a placement in alternative schools. Administrators will find themselves on the wrong side of the IDEA if they pursue suspensions that constitute a "change of placement" and if they do not ensure due process. In Honig v. Doe (1998), student, John Doe, was suspended for choking another student. Ultimately, the school officials unilaterally and nearly indefinitely suspended John Doe, which the Supreme Court found in violation. According to the majority opinion, because of the continued suspensions, the school officials created a "change of placement", which is a violation of IDEA. Hence, the discipline of John Doe, although needed to occur, was extreme and was not appropriate.

A suspension without a hearing involving three students is the focus of Goss v. Lopez (1975). The facts of this case pointed to blatantly disruptive students who destroyed school property, but because the administration did not hold a hearing for the students before suspensions were given, the students won the case. The lack of due process, which deprived the students of educational benefits (a property and liberty interest), caused the majority opinion of the Supreme Court to find in favor of the students. The suspensions were not questioned and the need for administrators to keep order on a school campus is always a priority. Due process, however, must be afforded to all students when students are suspended.

In the case of Seal v. Morgan (2000), a search and seizure turned up a knife (a dangerous weapon, as per the definition of the State of Tennessee) found in the glove compartment of a general education student's car and lead to an expulsion. Although the knife was kept in the car as protection from another student seeking retribution, the imposition of zero tolerance and discipline (expulsion) were the main drivers of this case. The $6^{\text {th }}$ Circuit Court found that school boards may impose any regulation or policy related to weapons, in order to keep order on a campus. Hence, an expulsion, which would be a change of placement, is appropriate when a school board's regulation or policy has been violated.

Other cases that are of interest to student discipline, due process, and change of placement are New Jersey v. T. L. O., 469 U.S. 325 (1985), Kowalski v. Berkeley County Schools, 10-1098 ( ${ }^{\text {th }}$ Circuit 2011), Tinker v. Des Moines Indep. Community Sch. Dist., 393 U.S. 503, 506 (1969), and Rosa R. v. Connelly, 889 F.2d 435, 439 (2d Cir. 1989).

The key to working through disciplining students in special education is to understand and know IDEA as well as state and local codes and policies. Furthermore, working with parents and communicating the expectations spelled out in the SCOC will help parents understand how discipline works on their student's campus and within the school district. School administrators should never fear disciplining students in special education, and they should be sure that the school environment is one that is safe and orderly for ALL students and staff.

\section{Teaching Notes or Guiding Questions}

When considering the case above, think about how the following questions could be answered according to your school district's policies and your state's codes. 


\section{Ml Macrothink}

1. Administrators will be faced with differing student violations to the student code of conduct, and how they work through them will be based on what the school's student code of conduct states. When it comes to those in special education, administrators need to understand how to discipline students without being afraid.

a. What mistakes did Mr. Murphy make in this case study? What did he do correctly?

b. If you were the principal of WSHS, what would you have done differently?

c. How does a principal educate himself/herself to know about the vast array of services that are given through special education?

2. All school districts have a discipline policy, specifically when placing students in an alternative discipline setting. Additionally, school districts have policies on how to proceed with placing students in special education in an alternative discipline setting.

a. What are the benefits of Mr. Murphy just allowing the arrest to occur and not doing anything administratively about disciplining Corey? What are the pitfalls?

b. What would you do if Corey was arrested? Would you hold a manifestation determination meeting and discipline hearing? Why?

3. What are some strategies you, as the principal, would use with a child with a disability that contributed to behavior issues?

4. Create a plan for this rural district to address the issues associated with the lack of alternate settings close by.

5. Discuss the benefits and drawbacks of the special education cooperative model this district uses?

6. Discuss the benefits of understanding case law that focuses on student discipline. What implications does case law have for school administrators?

The teaching notes and guiding questions are presented to help present and future administrators a chance to think about the fictional case study and apply learned knowledge in a manner where no consequences will occur.

\section{References}

Code of Federal Regulations. (2002). United States, 34 CFR $§ 300.530$.

Dustin W. Seal v. Allen Morgan, Superintendent, Knox County Board of Education, Defendants-Appellants, Vicki Dunaway, Principal, Powell High School, et al., 99-5090, 99-5600 (6 $6^{\text {th }}$ Circuit, 2000).

Dwyer, K. (1997). Disciplining students with disabilities. NASP Communique, 26(2). Retrieved from http://www.nasponline.org/publications/cq262discipline.html 


\section{Macrothink}

Journal of Education and Training

ISSN 2330-9709 2015, Vol. 2, No. 2

National Education Association. (2014). Education funding. Retrieved from http://www.nea.org/home/1019.htm

Texas Education Agency. (2013). Texas education directory. Retrieved from http://mansfield.tea.state.tx.us/tea.askted.web/Forms/Home.aspx

U.S. Supreme Court. (1975). Goss v. Lopez, 419 U.S. 565, 574-576 (1975).

U.S. Supreme Court. (1988). Honig, California Superintendent of Public Instruction v. Doe, et al., 484 U.S. 304 (1988).

\section{Copyright Disclaimer}

Copyright reserved by the author(s).

This article is an open-access article distributed under the terms and conditions of the Creative Commons Attribution license (http://creativecommons.org/licenses/by/3.0/). 